\title{
Effective development by relief suitability and transport infrastructure of the Obârșia Lotrului ski area
}

\author{
Laurenţiu Ilie, Laura Comănescu, Robert Dobre, Madalina Teodor \\ Geomorphology - Pedology - Geomatics Department \\ Faculty of Geography, University of Bucharest \\ Bucharest, Romania
}

\begin{abstract}
Relief and climatic conditions represent two defining elements for the development of a ski area in a mountain area. The study proposes an evaluation of parameters of particle morphology and morphographic relief, in order to identify the most suitable areas. The analysis of the slope and exposure of the hips, to which we can add the geology and the land cover, needs a high accuracy GIS project. The technical longitudinal profiles of the proposed slopes, represents a good tool for determining the slopes degrees of difficulty. At the same time, the study proposes the validation for the profitability rates of the ski area. The methodology focuses on two main stages. In the first stage, based on the GIS techniques, were identified the sustainability areas for the ski slopes, while in the second stage was conducted if the ski lift infrastructure is enough developed to serve the proposed ski domain.
\end{abstract}

Keywords - GIS; profitability rates; optimization; ski area; geomorphological factors; climatic factors

\section{INTRODUCTION}

The proposed study aims to capture the ideal framework between the ski lift infrastructure and the ski slopes in order to determine the profitability rates of the ski area. Although the study indicate if a second phase of ski lift infrastructure development is necessary.

\section{STUDY AREA}

The area selected for this study represents an "unexplored" one, from the Meridional Carpathians, in this case the Latoritei Mountains of the Parang group of Mountains. The Obârşia Lotrului resort, which will support the ski area, is the perfect support for this development. In addition to these favourable aspects (geomorphological and climatic factors) for the development of Obârşia Lotrului ski resort. Vidra resort which is situated near also indicates the suitability of the area for the development of the ski domain. [1]

The studied surface is approximate 565.0 ha. The area between Mount Miru and Obârşia Lotrului has 103 ha, lying between the North of the Lotru valley and the South of the Latoritei valley.

\section{SCOPE AND OBJECTIVES}

The first part of the methodology used to identify the suitability areas, is based on the technique of raster operations [2]. So they were reclassified in value intervals and resulted following maps: aspects map, geodeclivity map and the hypsometric map (see table of values). Afterwards each raster operations, a map is created. This map was reclassified into three classes of favourability of the snow areas. So the minimum favourability class is defined by the following parameters: lower altitude of 1200 meters, exposed to the south, southeast or southwest and geodeclivity between 5-15 degrees. The medium favourability class is characterized by favourable average altitude of 1200-1600 meters, East or West and geodeclivity between 15-35 degrees. The areas with high favourability are those over 1600 meters altitude, with an exhibition north and a geodeclivity above 35 degrees (geodeclivity above 35 degrees can be assigned for low favourability for winter sports, skiers exercises greater pressure on snow) [3].

TABLE I. TABLE OF VALUES AND THEIR INTERVALS CLASSIFICATION

\begin{tabular}{|c|c|c|c|c|c|c|}
\hline No. & $\begin{array}{c}\text { Asp } \\
\text { ect }\end{array}$ & $\begin{array}{c}\text { Favo } \\
\text { urabi } \\
\text { lity }\end{array}$ & $\begin{array}{l}\text { Geode } \\
\text { clivity }\end{array}$ & $\begin{array}{c}\text { Favour } \\
\text { ability }\end{array}$ & $\begin{array}{c}\text { Altitu } \\
\text { de }\end{array}$ & $\begin{array}{c}\text { Favour } \\
\text { ability }\end{array}$ \\
\hline 1. & $\mathrm{~N}$ & \multirow[b]{2}{*}{ high } & 5-15 & small & $<1200$ & small \\
\hline 2. & N-E & & $15-25$ & \multirow{2}{*}{ average } & $\begin{array}{c}1200- \\
1600\end{array}$ & average \\
\hline 3. & $\mathrm{E}$ & $\begin{array}{c}\text { avera } \\
\text { ge }\end{array}$ & $25-35$ & & $>1600$ & high \\
\hline 4. & S-E & \multirow{3}{*}{ small } & $35-45$ & high & & \\
\hline 5. & $\mathrm{~S}$ & & & & & \\
\hline 6. & S-V & & & & & \\
\hline 7. & V & $\begin{array}{c}\text { avera } \\
\text { ge }\end{array}$ & & & & \\
\hline 8. & $\begin{array}{l}\mathrm{N}- \\
\mathrm{V}\end{array}$ & high & & & & \\
\hline
\end{tabular}


The efficiently development of ski areas is when the length of the ski slopes is greater than 3.5 times the lift installation. By applying this method on existing domains from Romania, we can conclude that we have six domains that exceed the parameter of rentability. In this category falls six ski domains in the country: (Șureanu - 5.14, Snow Parc Ciumani - 4.53, Drumul Tătarilor - 4.27, Buskat Ski\& Summer Resort - 3.6, Borsec - 3.59 and Semenic 3,53). To determine the optimum number of skiers who may find simultaneously themselves on a ski slope was considered that the optimum distance is 12 meters between them. The ski slope areas were divided by a square (144 square meters) to obtain the number of squares covering ski area. To determine the optimum number of skiers who can simultaneously be on a slope, knowing the number of squares covering the surface of the ski area the following formula is applied: $\mathrm{O}=2 \mathrm{P}+2$ where $\mathrm{O}=$ the optimum number of skiers, $\mathrm{P}=$ the numbers of the squares [4].

\section{RESUltS}

To determine the optimal development of the Obârşia Lotrului proposed ski area, we apply the model identified. This may indicate whether the proposed development of cableway infrastructure has a required capacity for the slopes surface designed for an optimum number of skiers. The total area of slopes identified is $2046300 \mathrm{~m}$, which divided by $144 \mathrm{~m}$ and is resulted a total of 14210 square. Applying the formula $\mathrm{O}=2 \mathrm{p}+2$ [4], there is an optimum number 28422 skiers. The total capacity of cableway infrastructure proposed is estimated at 2773 people in 15 minutes, so the estimated maximum hourly capacity is 11 092 skiers per hour.

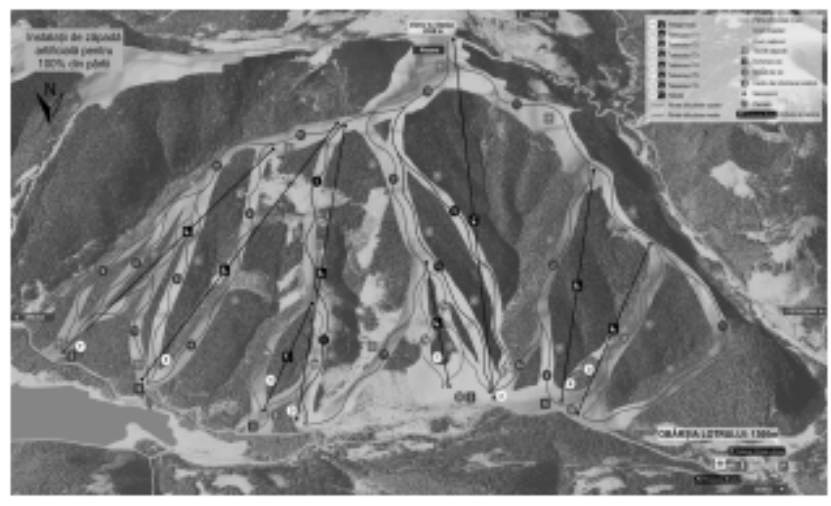

Figure.1 The proposed ski domain - Obârșia Lotrului (panoramic map)

\section{CONCLUSIONS}

By applying the model, we identified an underdevelopment cableway infrastructure which is half the optimum capacity of skiers. This result indicates that in this area is necessary to develop new cableway infrastructure

\section{REFERENCES}

[1] C.A. Tudor, I.C. Ioja, I. Patru-Stupariu, M.R. Nita, and A.M. Hersperger, "How successful is the resolution of land-use conflicts? A comparison of cases from Switzerland and Romania”, Applied Geography, vol. 47, pp. 125-136, 2014.

[2] M. Voiculescu and A. Onaca, "Snow avalanche assessment in the Sinaia ski area (Bucegi Mountains, Southern Carpathians) using the dendrogeomorphology method”, Area, vol. 45, pp. 109-122, 2013.

[3] M. Teodor and R. Dobbre, "Relief Suitability for Developing a Macro Ski Area between Predeal and Azuga Resorts”, Revista de Geomorfologie, vol. 17, pp. 95-106, 2015.

[4] Teodor M, Proiectarea, dezvoltarea și managementul domeniilor schiabile din România, teză de doctorat, 2016. (in Romanian) 